\title{
Problems and Strategies in English Translation of Quranic Divine Names
}

\author{
Fazel Asadi Amjad \\ Associate Professor of English Language Department \\ Kharazmi University, Tehran, Iran \\ E-mail: asadi@tmu.ac.ir \\ Mohammad Farahani (Corresponding author) \\ MA in Translation Studies, Kharazmi University, Tehran, Iran \\ E-mail: Farahani.mohammad.gh@gmail.com
}

Received: December 5, 2012 Accepted: January 5, 2012 Published: February 23, 2013

doi:10.5296/ijl.v5i1.3301ＵRL: http://dx.doi.org/10.5296/ijl.v5i1.3301

\begin{abstract}
The present research was an attempt to see how Quranic Divine Names (DNs) were translated into English by three professional translators namely, Shakir (1985), Qarai (2003), and Nikayin (2006) who provided their translations in prose, phrase-by-phrase, and poetry forms respectively. Firstly, the problems which the translators met for attaining lexical adequacy and semantic equivalence were explored. Secondly, the type and extent of strategies adopted by these three translators for overcoming the problems were described. Finally, the translators` works were compared and implications drawn. The findings of the study showed that the lexical compression of the original DNs and their emotive overtones and effects caused the main body of problems for the translators. Furthermore, it was found out that the most frequent strategies adopted by Shakir and Qarai were 'near-synonymy' and 'expansion' respectively. Nikayin, however, used these two strategies almost to an equal extent as his most frequent strategies.
\end{abstract}

Keywords: Divine name, Semantic equivalence, Problem, Translation strategy 


\section{Introduction}

About more than eighty percent of about 1.5 billion population of the Muslims do not know Arabic and use translation as a means to understand the meanings and messages of the Holy Quran. A considerable amount of these Muslims read the English translations of this Holy Book. So it seems necessary to pay due attention to the way these translations are done.

The selection of linguistic items of the target language repository for conveying the meaning of the source text is of great importance in every act of translation and the translator tries his/her best to find the most appropriate equivalents for the source text linguistic items. But the problem appears as there is no complete equivalence between the corresponding linguistic items of the two language systems, Arabic and English in the case of this study. The problem is even aggravated as the Quranic Arabic is a Quranic-specific language.

So this would cause noticeable problems for the Quran translators. As Reiss (2000: 53) puts it, considering the semantic components of a text is a crucial factor for preserving the content and meaning of the original text and if the translator ignores them, much room will be left for criticism. The same is true about the DNs as they are part of original Quranic text and cause difficulty for translators during the process of meaning rendering.

The present research takes a corpus-based approach to describe how the components of the original text have been adequately carried over to the target language. The focus of this study, therefore, is to discuss the problems and strategies concerning Quranic DN translation. It aims to consider and describe the strategy types and extents adopted by three professional Quran translators who are assumed to have done their best to reach lexical adequacy and semantic equivalence in translation of Quranic DNs.

\section{Literature Review}

\subsection{Translating the Holy Quran}

As Arberry (1973: x) puts it, the Quran is neither prose nor poetry, but a unique fusion of both. So it is clear that a translator cannot imitate its form as it is a Quranic-specific form having both the features of prose and poetry and utilizing beautifully the peculiar properties of the original language. Moreover, its form is so delicately fused with its content that neither form-focused nor content-focused translation can reproduce an equivalent translation in terms of either form or content.

The notion of equivalence at different levels has always been an indispensable concept in translation studies and Quran translation, of course. As Abdul-Raof (2001: 7) puts it 'one cannot deny the centrality of equivalence in translation theory; it will continue to dominate translation training programs and translation in general'. He believes that "whether at a micro-level or at a macro-level, one cannot achieve absolute symmetrical equivalence for languages since their multiple layers of meaning and their cultures in which they flourish are drastically different'. So each translator may focus on a specific kind of equivalence, e.g. denotative, aesthetic and translate accordingly ending up with a different translation.

According to Baker (1992), the difficulty and problem in translating from one language into 
another is posed by the concept of non-equivalence, or lack of equivalence. This problem appears at all language levels starting from the word level to the textual level. By non-equivalence at word level, she means the lack of a direct target language equivalent item for a source language item. The type and level of difficulty posed may vary to a large extent depending on the nature of non-equivalence. Different kinds of non-equivalence require different strategies, some very straightforward, others more involved and difficult to handle (Baker 1992: 20).

\subsection{Translating DNs in Context}

Saffarzadeh (2001: 1542), argues that the greatest values of the Holy Quran which many commentators and translators have failed to translate justly and accurately are Divine Names known as Asmā ul Hosnā in Arabic. This factor, she believes, is the major flaw which has caused confusion and brought about an evident sign of incompleteness of the meanings of the Words of Revelations throughput the Holy Quran. She maintains that 'any translation viod of attention to these meanings which usually confirm and complete each verse loses a substantial part of its validity'.

One of the problems encountered by translator of the Quran is how to deal with collocations. According to Armstrong (2005: 97), while selectional restriction has to do with the constraints that prevent words co-occurring in ways that produce nonsense, collocational restriction operates to produce largely arbitrary variation between near-synonyms. The difference between near-synonyms will be revealed through the context in which they appear. As Baker (1992: 47; quoted in Armstrong 2005: 97) points out, collocation has to do with 'semantically arbitrary restrictions which do not follow logically from the propositional meaning of the word'. The difficulty for the translator is not so much to recognize an SL collocation as to find an acceptable TL equivalent, taking care not to be led astray by the TL form into a literal translation that might be stilted or even misleading.

\subsection{Corpus-based and Descriptive Translation Studies}

In the past few years, researchers have started to use corpora in translation studies and develop corpora specifically for this use. This evolution shows an interest in the pursuit of a more satisfying theoretical account of the phenomenon of translation itself. Mona Baker first posed the idea of using corpus linguistics tools to study product and process of translation from a descriptive rather than a prescriptive point of view. As Laviosa puts it, 'if Gideon Toury can be righty regarded the father of Descriptive Translation Studies, Mona Baker well deserves the affectionate title of mother of Corpus-based descriptive Translation Studies' (Laviosa 2002: 18).

Baker (1993) argues that translation studies has reached a stage in its development as a discipline when it is both ready for and needs the techniques and methodology of corpus linguistics in order to make a major leap from prescriptive to descriptive statements, from methodologising to proper theorizing, and from individual and fragmented pieces of research to powerful generalizations' (Baker et al. 1993: 248). Corpus-based Translation Studies has strong links with target-oriented and Descriptive Translation Studies with regard to its object 
of study while at the same time it envisages a methodology which draws on the insights and the analytical tools of a linguistic perspective (Laviosa 2002: 22).

According to Toury (1995: 1), no empirical science can make a claim for completeness and (relative) autonomy unless it has a proper descriptive branch [emphasis original]. He recognizes describing, explaining and predicting phenomena pertaining to its object level as the main goal of such a discipline. He maintains that 'carefully performed studies into well defined corpuses, or sets of problems, constitute the best means of testing, refuting, and especially modifying and amending the very theory, in whose terms research is carried out'.

Taking the related literature reviewed above and drawing on a multilingual corpus named Noor Comprehensive Commentary Collection, the researcher tries to conduct a descriptive comparative study on the works of the three professional Quran translators concerning the strategies they used for translation of the Quranic Arabic DNs.

\section{Methodology of the Study}

\subsection{Corpus and method of analysis}

In doing this research, the researcher selected three English translations of the Holy Quran in order to compare and contrast them with the original Arabic text. These three translations were done by Muhammad H. Shakir (1985), Sayyed Ali Quli Qarai (2003), and Fazlollah Nikayin (2006). In fact, Nikayin`s translation is the first poetic translation of the Holy Quran in which he has tried to "carry over into the English language some of the beauty and sublimity, elegance and eloquence and the enhancing force of the original [...] which in the Quran, are always lying between prose and poetry'(See Nikayin`s translation Foreword). Another translator, namely Qarai, has adopted a phrase-by-phrase approach in his translation to bring some of the advantages of the interlinear translations to English-speaking readers of the Holy Qur'an letting the readers possessing an elementary knowledge of Arabic follow the meaning of the Arabic text of the Quran (See Qarai`s translation preface). Finally, Shakir has presented a standard prose translation of the Holy Quran.

This study follows the taxonomy suggested by Chesterman (1997) for translation strategies. It also makes use of Abdul-Raof s (2001) framework of study on the Quranic discourse. In Chesterman`s model, translation strategies are divided into two main parts:

a) Comprehension strategies: the analysis of the source text and the whole nature of the translation commission

b) Production strategies: the results of various comprehension strategies i.e. how the translator manipulates the linguistic material in order to produce an appropriate target text.

The second part is comprised of three sections namely, syntactic, semantic, and pragmatic strategies: 
Table 1. Chesterman`s Production Strategies

\begin{tabular}{|c|c|c|}
\hline Syntactic strategies & Semantic strategies & Pragmatic strategies \\
\hline $\begin{array}{l}\text { literal translation } \\
\text { loan, calque } \\
\text { transposition } \\
\text { unit shift } \\
\text { phrase structure change } \\
\text { clause structure change } \\
\text { sentence structure change } \\
\text { cohesion change } \\
\text { level shift } \\
\text { scheme change }\end{array}$ & $\begin{array}{l}\text { synonymy } \\
\text { antonymy } \\
\text { hyponymy } \\
\text { converse } \\
\text { abstraction change } \\
\text { distribution change } \\
\text { emphasis change } \\
\text { paraphrase }\end{array}$ & $\begin{array}{l}\text { cultural filtering } \\
\text { explicitness } \\
\text { information change } \\
\text { interpersonal change } \\
\text { illocutionary change } \\
\text { coherence change } \\
\text { partial translation } \\
\text { visibility change } \\
\text { transediting } \\
\text { other pragmatic changes }\end{array}$ \\
\hline
\end{tabular}

\subsection{Procedures}

1) The 26 selected DNs were spotted through the Holy Quran and the total number of their occurrences in the whole Quran was determined. In doing this job, the software Noor Comprehensive Commentary Collection was used. The researcher looked up and collected 1203 translation cases of these DNs, 401 cases belonging to each translator. The number of occurrences was different from one DN to another, ranging from 1 to more than 150 cases.

2) As some DNs like الملك (Prophet Joseph), العزيز (of Egypt), المومن (a faithful Muslim), البصير (a person who can see), referred to both the Almighty God and other entities, those which referred to the referents other than God, were excluded and omitted.

3) Taking a descriptive and comparative methodology and utilizing Chesterman`s model, the strategies the translators had adopted were coded. The variety of rendered equivalents and consistency of translators performances were investigated. Where applicable, the differences in the grammatical patterns of English and Arabic, collocational clashes, shifts, word order change and some other factors were discussed. To comply with the analysis part of Chesterman`s model, a short introduction to each DN was provided for the analysis of the meanings and implications of each DN based on a reliable Islamic scholarly website, namely Qul (http://qul.org.au/the-holy-quran/asma-ul-husna).

4) Finally, the concluding tables and graphs were provided to show the frequency of each translator`s strategy adoption.

\section{Discussion and Results}

\subsection{Examples from the corpus}

In this section, a number of instances out of 26 cases of DN translation under investigation are provided. At first, the meanings of each DN unpacked based on Qul website. Then each instance is followed by an analysis table and relevant explanation or discussion. 


\subsubsection{Translation of التَللِك}

The Divine Name المَلِ consists of the following meanings and implications according to Qul website:

Al-Malik conveys the meaning of 'One Who is free, by virtue of His Own merits and characteristics; from depending on anything in existence, while everything in existence depends on Him.' Nothing in existence can do without Him, whereas everything that exists derives its existence from Him or because of Him. Everything/everyone is His. (http://qul.org.au/the-holy-quran/asma-ul-husna)

Table 2. Translation of المَلِّك

\begin{tabular}{|l|l|l|l|}
\hline Shakir & \multicolumn{1}{|c|}{ Qharai } & \multicolumn{1}{c|}{ Nikayin } \\
\hline King & 5 near-synonymy & & 1 near-synonymy \\
\hline Sovereign & & 5 near-synonymy & 2 near-synonymy \\
\hline Sovereign Lord & & & 2 expansion \\
\hline
\end{tabular}

There are five instances of this DN in the Holy Quran which refer to the Almighty God. In all of these cases Shakir has chosen the equivalent 'king' as the nearest synonym for الملك and put aside other alternatives while Qarai's decision has been in favor of 'sovereign' considering it as more adequate for this DN. This can proves of Levy`s claim, considering translation as a decision process (Munday 2001: 62). Both Shakir and Qarai are consistent in their performance while Nikayin has chosen three different equivalents in these five cases.

\subsubsection{Translation of القدّوس}

Al-Qudoos means: the One Whose characteristics cannot be conceived by the senses, nor can He be conceived by imagination, nor can He be realized by any mind or reason or judged by any intellect. Linguistically, it is derived from "quds," purity or cleanness. [...] Al-Qudds is the One Who is above need and Whose Attributes are above being deficient. He is the One Who purifies the souls against sinning, Who takes the wicked by their forelocks, Who is above being limited to space or time. (ibid)

Table 3. Translation of القّّوس

\begin{tabular}{|l|l|l|l|}
\hline القدّوس| & Shakir & Qarai & Nikayin \\
\hline Holy & 2 near-synonymy & & \\
\hline All-holy & & 2 expansion & \\
\hline Ever-holy & & & 1 expansion \\
\hline Holiest & & & 1 emphasis change \\
\hline
\end{tabular}

Here both Shakir and Qarai have used one certain equivalent for the two occurrences of this $\mathrm{DN}$, though their selection of available alternatives is not the same. Nikayin, however, has decided to use two different equivalents in the two different contexts. The DN القدوس is in an Arabic grammatical form called Ism al-mubalegha (Hyperbolic Name) which is used to show the presence of a large amount of one characteristics in someone or something and has a 
strong effect. However none of the equivalents provided can adequately express the meanings and implications of the original DN. For example 'Holy' is a more general and neutral word which does not have the specific meaning of the original DN. Regarding 'All-holy' and 'Ever-holy' which have been assigned with 'expansion' strategy, it can be said that lexical compression, as an important feature of the Quranic discourse (Abdul-Raof 2001), have been impaired. Moreover, by providing 'Holiest' as the equivalent, Nikayin has shifted the emphasis from the DN itself to the comparison of the referent of this DN with other holy things.

\subsubsection{Translation of المؤمن}

Al-Mu'min means: the One to Whom peace and security are rendered: He provides the means of their attainment, blocking all the avenues of fear. There is neither peace nor security in this life against the causes of disease and perdition, nor in the life hereafter against the torment and the Wrath, except that He provides the means to attain it. (ibid)

Table 4. Translation of المؤمن

\begin{tabular}{|l|l|l|l|}
\hline المومن & Shakir & Qarai & Nikayin \\
\hline Granter of security & 1 paraphrase & & \\
\hline securer & & 1 near-synonymy & \\
\hline fount of safety & & & 1 paraphrase \\
\hline
\end{tabular}

There is only one instance of المومن in the Holy Quran which refers to the Almighty God as other instances refer to as for example the believers. For translation of this only example, Shakir has adopted the paraphrase strategy to reach the desirable adequacy while Qarai has preferred near-synonymy. He has chosen 'securer' which is a rare word and has a very low frequency. Nikayin has paraphrased this DN as 'fount of safety' to overcome the problem of inadequacy too. However, he has lost the linguistic compression feature of the Quranic discourse.

\subsubsection{Translation of الغقار}

Al-Ghaffar is one of Allah's Attributes derived from ghufr and ghufran, both nouns which convey the meaning of: veiling, hiding, concealing. Allah's maghifra, forgiveness, is His veiling of one's sins, and His forgiveness by granting him His favor and mercy. Al-Ghaffar is the One Who has manifested what is beautiful and veiled what is ugly in the life of this world and Who does not inflict His penalty on him in the life hereafter. (ibid) 
Table 5. Translation of الغقار

\begin{tabular}{|l|l|l|l|}
\hline Shakir & \multicolumn{1}{|c|}{ Qarai } & \multicolumn{1}{c|}{ Nikayin } \\
\hline great forgiver & 1 expansion & & \\
\hline All-forgiver & & 4 expansion & \\
\hline most Forgiving & 3 emphasis change & & 1 emphasis change \\
\hline Ever-pardoner & & & 1 expansion \\
\hline Forgiver & & & 1 near-synonymy \\
\hline Forgiving & & & 1 near-synonymy \\
\hline
\end{tabular}

In four cases of occurrence of this DN, Nikayin has used four different equivalents while Qarai has just used expansion strategy, providing a certain equivalent in the four cases. Shakir is mostly consistent as he adopts one strategy for three cases out of four. The presented equivalents, however, cannot have the same emotive effect as that of the original item. As Abdul-Raof puts it, Quranic emotive words have different layers of meaning with special emotive overtones; in translation, their emotive meanings are diluted as in the above example which has been given the simple meaning of (forgiveness) which gives a limited idea of God's mercy. The Quranic meaning implies more than `forgiveness'; it implies "grace which protects us and keeps us from sins, and indeed guides us to the light of His" (Ali 1983, as cited in Abdul-Raof 2001: 33).

\subsubsection{Translation of الو هّاب}

Al-Wahhab" is derived from the proper noun hibah the verb of which, yahib, means: to make someone else the owner of what the giver, the first party (the doer), rightfully owns without asking the second party for any compensation in return. (ibid)

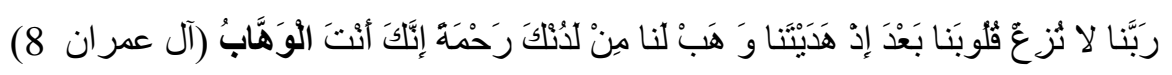

Shakir : Our Lord! make not our hearts to deviate after Thou hast guided us aright, and grant us from Thee mercy Surely Thou art the most liberal Giver(8)

Qarai: [ They say,] " Our Lord!

Do not make our hearts swerve

after You have guided us,

and bestow Your mercy on us.

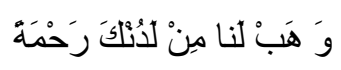

Indeed You are the All-munificent. ( 8)

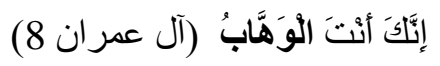

Nikayin : Our lord, now that You`ve guided us aright,

Let not our hearts become perverse and show

To us Your mercy, for you are indeed,

The greatest Mercy-Shower; 
Table 6. Translation of الو

\begin{tabular}{|l|l|l|l|}
\hline most liberal Giver & \multicolumn{1}{|c|}{ Shakir } & Qarai & \multicolumn{1}{|c|}{ Nikayin } \\
\hline Great Giver & $\begin{array}{l}\text { emphasis } \\
\text { change + expansion }\end{array}$ & & \\
\hline All-munificent & 1 expansion & & \\
\hline greatest Mercy-Shower & & 3 expansion & $\begin{array}{l}1 \text { emphasis change } \\
+ \text { expansion }\end{array}$ \\
\hline Magnanimous & & 1 near-synonymy \\
\hline $\begin{array}{l}\text { greatest Granter of } \\
\text { every bounty }\end{array}$ & $\begin{array}{l}1 \text { emphasis change } \\
+ \text { expansion }\end{array}$ \\
\hline
\end{tabular}

In 2 cases of occurrence of this DN, Shakir has used the equivalent 'most liberal giver`. The term 'liberal' usually invokes worldly affairs such as political and social ones as it is used mostly in these kinds of contexts. It can be easily attributed to human beings and cannot truly convey emotive overtones of the original DN. Qarai has complete consistency in adopting expansion strategy while Nikayin has used a different equivalent in each different Aya.

\subsubsection{Translation of الرزّاق}

Al-Razzaq" is derived from rizq, sustenance, or anything of any benefit to man, animals, plants, etc., whereby the latter are sustained or are helped in their growth. Rain is also called rizq; it helps sustain every living being on our planet. (ibid)

Table 7. Translation of الرزّاق

\begin{tabular}{|l|l|l|l|}
\hline Bestower of sustenance & Shakir & Qarai & Nikayin \\
\hline All-provider & & 1expansion & 1 expansion \\
\hline
\end{tabular}

The equivalents presented above are to a large extent less expressive than the original item being expanded or paraphrased by more than a single linguistic item.

\subsubsection{Translation of الفّّاح}

In Arabic, fataha, the verb, means "opened," and muftah means key, whereas fath means victory or conquest. Fath also means flowing water, a creek, or a river. It also means: to arbitrate between two opponents. [...] To say that Allah is al-Fattah is to say that He is the One Who judges between those whom He creates, His servants, the obedient ones and the rebellious. It is derived from fath which means, in such usage, arbitration or decision-making. [...] Al-Fattah is the One Who opens deadlocked matters and issues, Who reveals the truth, Who simplifies whatever seems to be complicated, Who controls the affairs of the heavens and the earth. (ibid) 
Table 8. Translation of الفّّاح

\begin{tabular}{|l|l|l|l|}
\hline greatest Judge & Shakir & Qarai & Nikayin \\
\hline Judge & $\begin{array}{l}1 \quad \begin{array}{c}\text { expansion+ } \\
\text { emphasis change }\end{array} \\
\text { Knowing Judge } \\
\text { Most Keen }\end{array}$ & 1 near-synonymy & \\
\hline
\end{tabular}

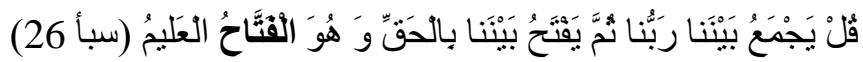

As mentioned above this DN has different layers of meaning. However, the translators have taken the 'judging' sense of this DN, as can be derived out of the context (Aya), and translated it accordingly. For translation of this DN, Nikayin has provided four linguistic items in translating one single original item and Shakir has provided two linguistic items. Qarai, however, has provided only one near-synonymous item.

\subsubsection{Translation of الثهيد}

The attribute "al-Shaheed" is derived from shuhood, [eye] witnesses, and it requires knowledge by observation: Allah is al-Shaheed because $\mathrm{He}$ is present and observes all beings whom He has created and whom He will create at any time and in any place, and He is fully aware of such beings. (ibid)

Table 9. Translation of الثهيد

\begin{tabular}{|l|l|l|l|}
\hline \multicolumn{1}{|c|}{ Shakir } & \multicolumn{1}{c|}{ Qarai } & \multicolumn{1}{c|}{ Nikayin } \\
\hline witness & 9 near-synonymy & 9 near-synonymy & 7 near-synonymy \\
\hline is watching & & & 1 transposition \\
\hline does witness & & & $\begin{array}{l}\text { 1transposition+ emphasis } \\
\text { change }\end{array}$ \\
\hline
\end{tabular}

There is another interesting point in here. In addition to the fact that both Shakir and Qarai have complete consistency in choosing one certain equivalence for a certain DN throughout the Holy Quran, the choice of both is the same. Even Nikayin's seven choices out of nine cases are the same as the other two translators'. This can show the fact that 'witness' is recognized, at least by these three translators, as the most adequate English equivalent for ' 'الثهيديد' than other alternatives such as observer, eyewitness, watcher, etc.

\subsection{Description of the Translators`Strategy Adoption}

The frequencies and percentages of translation strategies adopted by Shakir, Qarai, and Nikayin are presented in the tables and bar graphs below:

\subsubsection{Description of Shakir`s Translation Strategies}

The following table and graph describes the performance of Shakir: 


\section{Macrothink}

International Journal of Linguistics

ISSN 1948-5425

2013, Vol. 5, No. 1

Table 10. Frequency and Percentage of Shakir`s Adopted Strategies in DN Translation

\begin{tabular}{|l|l|l|}
\hline \multicolumn{1}{|c|}{ Adopted Strategy } & \multicolumn{1}{|c|}{ Frequency } & \multicolumn{1}{c|}{ Percentage } \\
\hline Near-synonymy & 314 & $78.3 \%$ \\
\hline Paraphrase & 5 & $1.2 \%$ \\
\hline Expansion & 21 & $5.2 \%$ \\
\hline Transposition & 53 & $13.2 \%$ \\
\hline Emphasis change & 5 & $1.2 \%$ \\
\hline $\begin{array}{l}\text { Emphasis change } \\
\text { Expansion }\end{array}$ & 3 & $0.7 \%$ \\
\hline Total & 401 & $100 \%$ \\
\hline
\end{tabular}

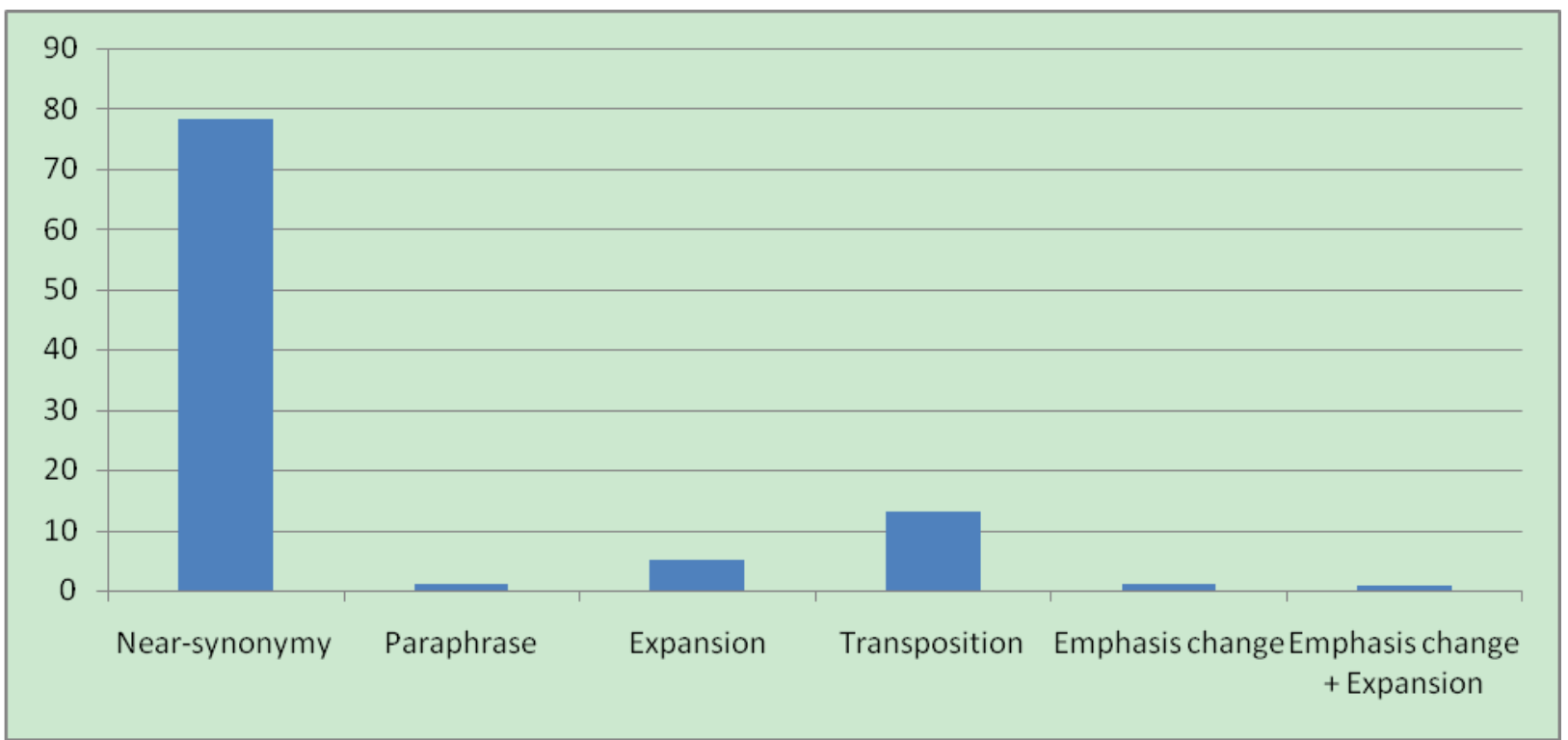

Figure 1. Percentage of Translation Strategies Adopted by Shakir in DN Translation

As the bar graph shows, Shakir employed 'near-synonymy' as his most frequent strategy. Next to this strategy, he has used transposition to a much lower extent. Other strategies have very low frequencies.

\subsubsection{Description of Qarai`s Translation Strategies}

The following table and graph describes the performance of Qarai:

Table 11. Frequency and Percentage of Qarai`s Adopted Strategies in DN Translation

\begin{tabular}{|l|l|l|}
\hline Adopted Strategy & Frequency & Percentage \\
\hline Near-synonymy & 16 & $3.9 \%$ \\
\hline Paraphrase & 21 & $5.2 \%$ \\
\hline Expansion & 310 & $77.3 \%$ \\
\hline Transposition & 4 & $0.9 \%$ \\
\hline Transposition + Expansion & 50 & $12.4 \%$ \\
\hline Total & 401 & $100 \%$ \\
\hline
\end{tabular}




\section{Ml Macrothink}

International Journal of Linguistics

ISSN 1948-5425

2013, Vol. 5, No. 1

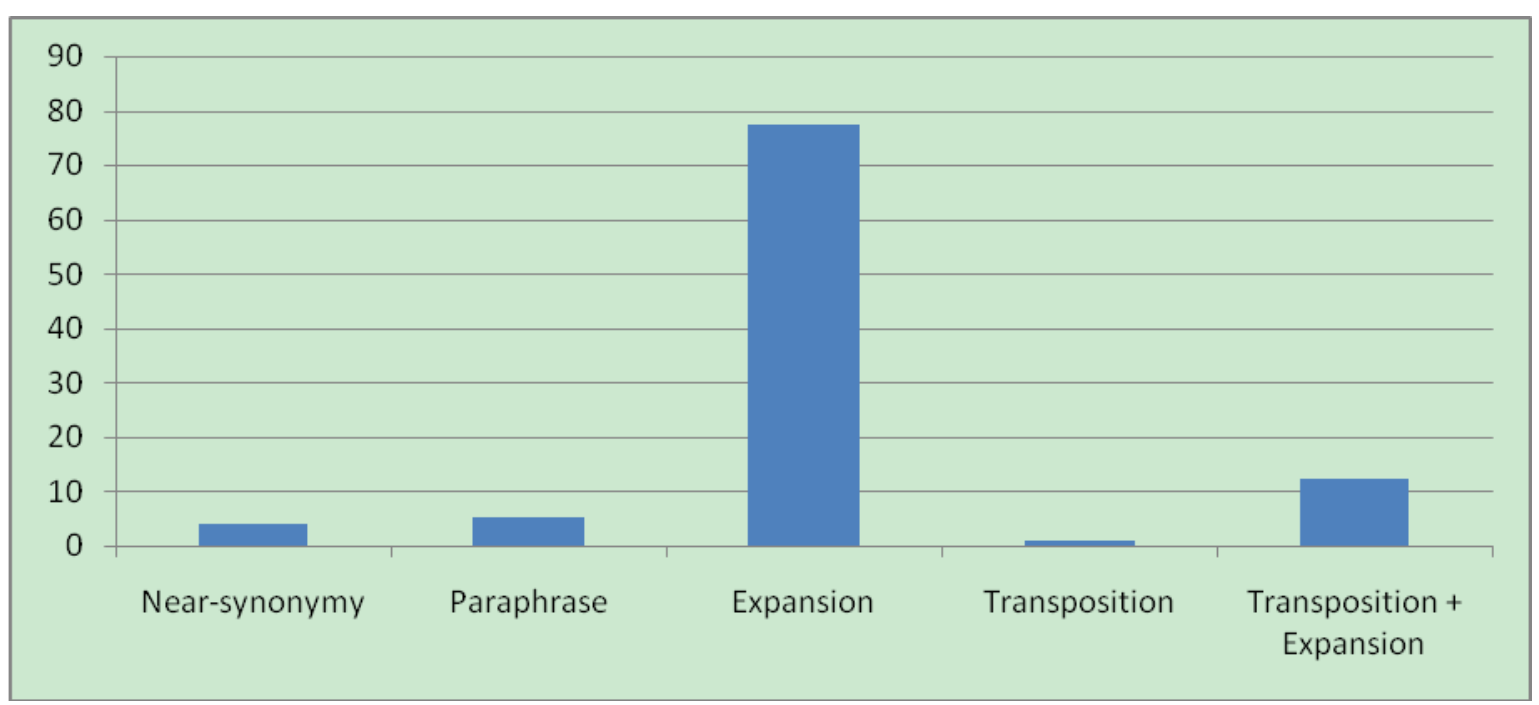

Figure 2. Percentage of Translation Strategies Adopted by Qarai in DN Translation

As shown in figure 2, 'expansion' is the most frequent strategy used by Qarai. Even his next frequent strategy is a combination of 'transposition' and 'expansion'. This reveals the translator`s interest in expansive strategies in his phrase-by-phrase translation.

\subsubsection{Description of Nikayin`s Translation Strategies}

The following table and graph describes the performance of Nikayin:

Table 12. Frequency and Percentage of Nikayin`s Adopted Strategies in DN Translation

\begin{tabular}{|l|l|l|}
\hline Adopted Strategy & Frequency & Percentage \\
\hline Near-synonymy & 137 & $34.1 \%$ \\
\hline Paraphrase & 57 & $14.2 \%$ \\
\hline Expansion & 128 & $31.9 \%$ \\
\hline Transposition & 24 & $5.9 \%$ \\
\hline Emphasis change & 25 & $6.2 \%$ \\
\hline Emphasis change + Expansion & 7 & $1.7 \%$ \\
\hline Emphasis change +Paraphrase & 5 & $1.2 \%$ \\
\hline Emphasis change + Transposition & 4 & $0.9 \%$ \\
\hline Transposition + Expansion & 14 & $3.4 \%$ \\
\hline Total & 401 & $100 \%$ \\
\hline
\end{tabular}




\section{Macrothink}

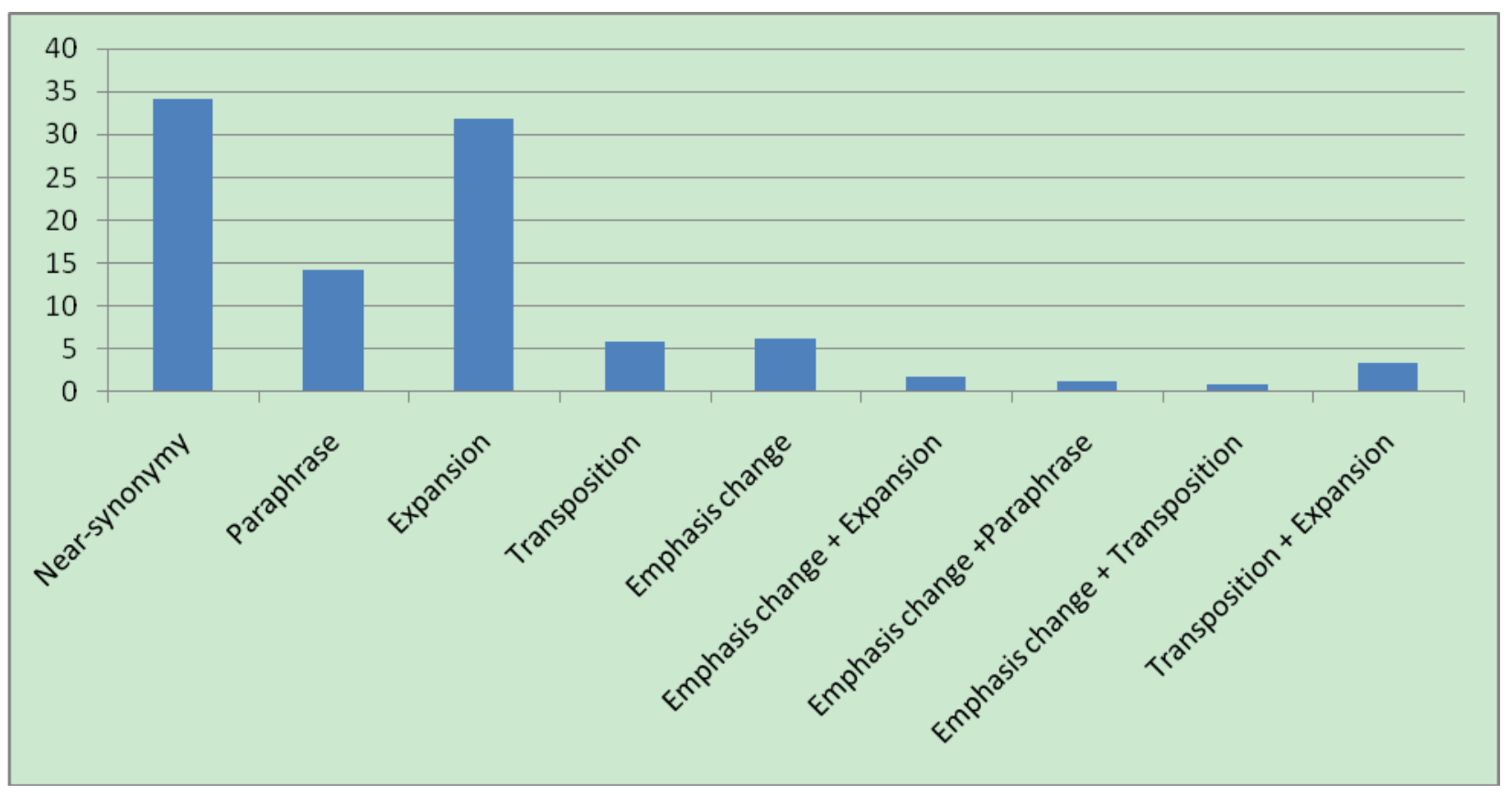

Figure 3. Percentage of Translation Strategies Adopted by Nikayin in DN Translation

As presented in figure 3, Nikayin has used the strategies 'near-synonymy (34.1\%)' and 'expansion (31.9\%)', almost to an equal extent. Next to them, 'paraphrase $(14.2 \%)$ ' and 'emphasis change $(6.2 \%)$ are the most frequent strategies. Other strategies have low frequencies. All in all, it is evident that he has used a variety of strategies in his poetic translation of the Holy Quran.

\section{Conclusion}

Based on the findings of the present study, it could be concluded that one of the main problems the Quran translators met in translation of DNs was the lexical compression of these Names as they were equipped with layers of meaning encapsulated in a sole linguistic item. Another main problem was the distortion of the emotive overtones and expressive effects that the original DNs created on the source language readers due to large cultural and structural difference between Arabic and English. Therefore, it is quite evident that providing an equivalent for an Arabic word in English can hardly save the specific emotive overtones and expressive effects of the original item. For example the Arabic morphological patterns like Ism Al-mobalegheh (Hyperbolic Name e.g. الغّار) or Sifat Al-Moshabbaheh (Perpetual Attribute e.g. العليم) caused a handful of problems for the translators as they had certain weights and effects in Arabic language structure which could not be similarly reproduced in English. The conversion of a DN into a verb using transposition strategy (by which the function of the DNs as having the possibility for calling the Almighty God through was obliterated) and differences in the frequencies and collocational restrictions of the original DNs in the source language and their counterparts in the target language were some other problems the Quran translators encountered to.

As to the strategies used by the three translators, it can be said that a variety of different strategies, mostly semantic strategies, were adopted. However, the extent of adoption of each 
translation strategy was different from one translator to another.

In adopting the 'expansion' strategy, Qarai took the first position among the translators (77.3\%). Even in his second most frequent strategy which is a combination of expansion and transposition, one part of his couplet strategy is 'expansion'. This shows that Qarai had a strong inclination toward this strategy and considered it as the most appropriate one for attaining semantic equivalence and lexical adequacy in a phrase-by-phrase translation. As claimed by himself, Qarai took a phrase-by-phrase or 'mirror-paraphrasing' approach 'to enable the readers possessing an elementary knowledge of Arabic to follow the meaning of the Arabic text of the Quran' (See Qarai`s translation preface).

Shakir, however, preferred 'near-synonymy' strategy to other strategies as he used it in $78.3 \%$ of his DN translation cases. Next to this strategy, he adopted 'transposition' strategy by $13.2 \%$. Both of these strategies produce the equivalents with a single brief linguistic item. This may have the implication that this translator has attempted to save the brevity in his English renderings compared to lexical compression of the original items.

And regarding the strategies adopted by Nikayin, it was found out that he has used the strategies 'near-synonymy (34.1\%)' and 'expansion (31.9\%)', almost to an equal extent. Other strategies were used to a normal extent; that is, there was no insistence on the part of this translator on using a certain strategy to a large extent or to a small extent. This may be because of the translator's focus on saving the poetical spirit of the original text in the translated version without a special concern for the type of strategies and variety in equivalents.

Since the Holy Quran has many beautiful features in terms of both form and content, no single translated version can ever encapsulate all these features. Even no combination of all translated versions can ever cover all the beautiful features of the original text. Therefore, it can be suggested that it cannot suffice to read only one translated version of the Holy Quran for those who do not know the original language. Although the non-native speakers of Arabic cannot receive the same effect as that created on the original readers, the more successful translated versions they read, the more approximate they become to the original text.

\section{References}

Abdul-Raof, H. (2001). Quran Translation - Discourse, Texture and Exegesis. Richmond: Curzon.

Arberry, A. J. (1973). The Koran Interpreted. New York: The Macmillan Company.

Armstrong, N. (2005). Translation, Linguistics, Culture: A French-English Handbook. Clevedon, Buffalo and Toronto: Multilingual Matters Ltd.

Baker, M. (1992). In Other Words: A Coursebook on Translation, London and New York: Routledge. http://dx.doi.org/10.4324/9780203327579 


\section{Macrothink}

International Journal of Linguistics

ISSN 1948-5425

2013, Vol. 5, No. 1

Baker, M. (1993). Corpus Linguistics and Translation Studies: Implications and Applications. In: M. Baker, G. Francis and E. Tognini-Bonelli, eds. Text and Technology: In Honour of John Sinclair. Amsterdam and Philadelphia: John Benjamins, pp. 233 - 50.

Chesterman, A. (1997). Memes of Translation: The Spread of Ideas in Translation Theory. Amsterdam: John Benjamins.

Laviosa, S. (2002). Corpus-based Translation Studies: Theory, Findings, Applications. Amsterdam and New York: Rodopi B.V.

Munday, J. (2001). Introducing Translation Studies. Theories and Applications, London: Routledge.

Nikayin, F. (2006). THE QURAN: The First Poetic Translation. Skokie, Illinois: The Ultimate Book, Inc.

Noor Comprehensive Commentary Collection. (2010). DVD-ROM. Qom: Computer Research Center of Islamic Sciences.

Qarai, A. (2003). The Quran with an English Paraphrase. Qom: The Center for Translation of Holy Quran.

QUL website. (2011). Asma-ul-Husna. Retrieved from http://www.qul.org.au/the holy quran/asma-ul-husna

Reiss, K. (1971). Möglichkeiten und Grenzen der Übersetzungskritik, Munich: M. Hoeber. Trans. E. F. Rhodes (2000). Translation Criticism: The Potentials and Limitations, Manchester: St Jerome and American Bible Society.

Saffarzaheh. (2001). The Holy Quran: English and Persian Translation with Commentaty. Tehran: Honar Bidari Publisher.

Toury, G. (1995). Descriptive Translation Studies - and Beyond. Amsterdam and Philadelphia: John Benjamins. 